\title{
Jujubinus browningleeae n. sp. (Gastropoda Trochidae) from the Atlantic Ocean, a new member of the "smooth" Jujubinus Monterosato, 1884 complex
}

\author{
Carlo Smriglio'*, Paolo Mariottini' \& Frank Swinnen² \\ ${ }^{1}$ Dipartimento di Scienze, Università “Roma Tre”, Viale Marconi 446, 00146 Roma, Italy; e-mail: csmriglio@alice.it; \\ paolo.mariottini@uniroma3.it \\ ${ }^{2}$ Lutlommel 10, B 3920 Lommel, Belgium; e-mail: f.swinnen@skynet.be \\ ${ }^{*}$ Corresponding author
}

\begin{abstract}
A new species of the gastropod family Trochidae Rafinesque, 1815, Jujubinus browningleeae n. sp., based on morphological characters of the shell, is here described. The new taxon is actually known only from the Gorringe Bank, located off Cape St. Vincent (Portugal, NorthEastern Atlantic). The new taxon is compared with members of the $J$. curinii species complex, which are morphologically the most similar congeners.
\end{abstract}

KEY WORDS

Trochidae; Jujubinus browningleeae n. sp.; species complex; Atlantic Ocean.

Received 12.09.2018; accepted 25.10.2018; printed 30.12.2018; published online 07.01.2019

\section{INTRODUCTION}

The genus Jujubinus Monterosato, 1884, includes a small group of marine cantharidine trochid (Gastropoda Trochidae Cantharidinae) living mostly in the lower intertidal zone down to about 80-100 m depth and are constantly associated with algal turfs and marine sea-grass beds (Mariottini et al., 2013 and references therein). Jujubinus curinii Bogi et Campani, 2006, was the first species of this genus showing a peculiar shell sculpture, consisting of flat spiral cords without lamellae between the spiral threads (Bogi \& Campani, 2006). In fact, the typical shell of Jujubinus displays an evident sculpture consisting of 4 to 8 spiral cords variable in size, often beaded and with tiny prosocline lamellae within interspaces between spiral threads (Monterosato, 1884). Recently, three other species with similar "smooth" shell morphology have been described by Smriglio et al.
(2014, 2015), i.e., J. eleonorae Smriglio, Di Giulio et Mariottini, 2014, and J. trilloi Smriglio, Di Giulio et Mariottini, 2014, from the Sicily Channel, and $J$. alboranensis Smriglio, Mariottini et Oliverio, 2015, from the Alborán Sea. Noteworthy, all members of this complex are endemics, with a very spotted distribution: the Strait of Messina (J. curinii); two offshore marine shoals of the Sicily Channel, i.e., Skerki Bank (J. eleonorae) and Talbot Bank (J. trilloi); Alboran Island, Western Mediterranean Sea (J. alboranensis). In the Atlantic Ocean, seamounts are isolated undersea mountains showing extraordinary submarine topographies, since they uprise steeply from the abyssal plain reaching the photic layer of shallow water seafloors, generally creating suitable habitats for benthic algae (Staudigel et al., 2010; HallSpencer et al., 2011).

The Gorringe Bank is a part of the Horseshoe seamounts range and Paleo Madeira (Madeiran 
volcanic province), belonging to the African tectonic plate and separated from Europe by the Azores-Gibraltar fracture zone (Fernández-Palacios et al., 2011). In particular, the Gorringe seabank is over $180 \mathrm{~km}$ long (Anonymous, 2005) and is located southwest of Cape St. Vincent (Portugal, North-Eastern Atlantic). This latter seabank rises from $5,000 \mathrm{~m}$ of depth to the photic zone with peaks of $<50 \mathrm{~m}$ below sea level and its surface is composed of recent conglomerates and lava flows with some areas of exposed carbonate rock (Anonymous, 2005). In the present paper, a new taxon from the Gorringe Bank is described, $J$. browningleeae $\mathrm{n}$. sp., on the basis of morphological shell characters. The new taxon is compared with members of the $J$. curinii species complex, which are morphologically the most similar congeners. The new species is another endemic "smooth" Jujubinus, being currently known only from the Gorringe Bank.

\section{MATERIAL AND METHODS}

Specimens of J. browningleeae $\mathrm{n}$. sp. were collected while SCUBA diving (30 m depth). Scanning Electron Microscopy (SEM) photographs were taken at the Interdepartmental Laboratory of Electron Microscopy (LIME, Università "Roma Tre", Rome, Italy), using a Philips XL30. Current systematics here adopted is based on World Register of Marine Species (WoRMS, http://www. marinespecies.org/; last access September 2018).

ABBREVIATIONS AND ACRONYMS. CSPM: Carlo Smriglio-Paolo Mariottini collection, Rome, Italy; D: Diameter; FS: Frank Swinnen collection, Lommel, Belgium; H: Height; RBINS: Institut Royal des Sciences Naturelles de Belgique, Brussels, Belgium; LIME: Interdepartmental Laboratory of Electron Microscopy; SEM: Scanning Electron Microscopy.

\section{RESULTS}

\section{Systematics}

Classis GASTROPODA Cuvier, 1795

Familia TROCHIDAE Rafinesque, 1815

Genus Jujubinus Monterosato, 1884
TYPE SPECIES. Trochus matonii Payraudeau, 1826 =Jujubinus exasperatus (Pennant, 1777, by subsequent designation of Crosse, 1885).

\section{Jujubinus browningleeae $\mathrm{n}$. $\mathrm{sp}$.}

(Figs. 1-6, 7-17, 22)

DiAGNOSIS. Small and slightly turriculate shell, sculpture consisting of flat spiral cords demarcated by incised spiral lines, prosocline lamellae absent between cords.

TYPE MATERIAL. 2 shells from the type locality: Gorringe seamount Bank, 130 miles off Cape St. Vincent, Portugal North-Eastern Atlantic. Holotype: RBINS: I.G.33787/MT.3687; paratype FS.

OTHER EXAMINED MATERIAL. 200 specimens of J. curinii from Scilla (Strait of Messina, Mediterranean Sea) (CS-PM); 122 specimens (type material) of J. eleonorae from the Skerki Bank (Sicily Channel, Mediterranean Sea) (CS-PM); 90 specimens (type material) of $J$. trilloi from the Talbot Bank (Sicily Channel, Mediterranean Sea) (CSPM); 122 specimens (type material) of J. alboranensis from the Alborán Island $\left(35^{\circ} 56^{\prime} 43.99^{\prime \prime} \mathrm{N}\right.$ $3^{\circ} 02^{\prime} 03.73^{\prime}$ W), Alborán Sea, (Western Mediterranean Sea) (CS-PM).

Description of THE HOLOTYPE. Shell of relatively small size for the genus. Shell conical, 5.2 $\mathrm{mm}$ in height $(\mathrm{H}), 3.8 \mathrm{~mm}$ in diameter (D). Protoconch smooth, of 1.5 whorls, $410 \mu \mathrm{m}$ width. Teleoconch of 5.5 slightly convex whorls. Sculpture consisting of 6 flat, spiral cords, regularly spaced, slightly shouldered and ratchet and demarcated by incised spiral lines. Basal cord evident, flat and slightly larger than spiral ones. Suture well incised. Teleoconch surface entirely covered by evident prosocline growth striae. Base convex, umbilicus closed and covered with a whitish callus. Aperture quadrangular, with the columellar callus thickened in the middle portion. Interior of the aperture whitish, nacreous. Colour of protoconch and small portion of the apical teleoconch whorl reddish, remaining whorls and base uniformly dark-brown with axial wavy and narrow yellow stripes.

VARIABILITY. The paratype 3.8 (H) X 3.3 (D) $\mathrm{mm}$ shows a protoconch of 1.5 whorls $(370 \mu \mathrm{m}$ 
width). Its teleoconch has 4.5 whorls, with 5 flat spiral cords, not regularly spaced, slightly shouldered and ratchet and demarcated by incised spiral lines. Basal cord evident only on the last whorl. Teleoconch surface entirely covered by visible prosocline growth striae. Base slightly convex, umbilicus closed and covered with a whitish callus. Aperture quadrangular, with the columellar callus thickened in the middle portion. Interior of the aperture whitish, nacreous. Colour of protoconch and teleoconch whorls bright reddish, basal cord with yellow wavy lines and base uniformly yellow dotted with red stripes. The most striking difference observed between the holotype and the paratype shells is the teleoconch colour, indicating a great variability of this character.

Distribution And Biology. This new species is only known from the type locality. Jujubinus browningleeae $\mathrm{n}$. $\mathrm{sp}$. were collected while SCUBA diving (30 $\mathrm{m}$ depth) on a rocky bottom covered with algae reefs of the Gorringe Bank, $36^{\circ} 35^{\prime} 0^{\prime \prime} \mathrm{N} 11^{\circ} 25^{\prime} 0^{\prime \prime} \mathrm{W}, 130$ miles off Cape St. Vincent, Portugal North-Eastern Atlantic.

ETYMOLOGy. This species is named after Mrs Sarah Browning-Lee in recognition of her continu-
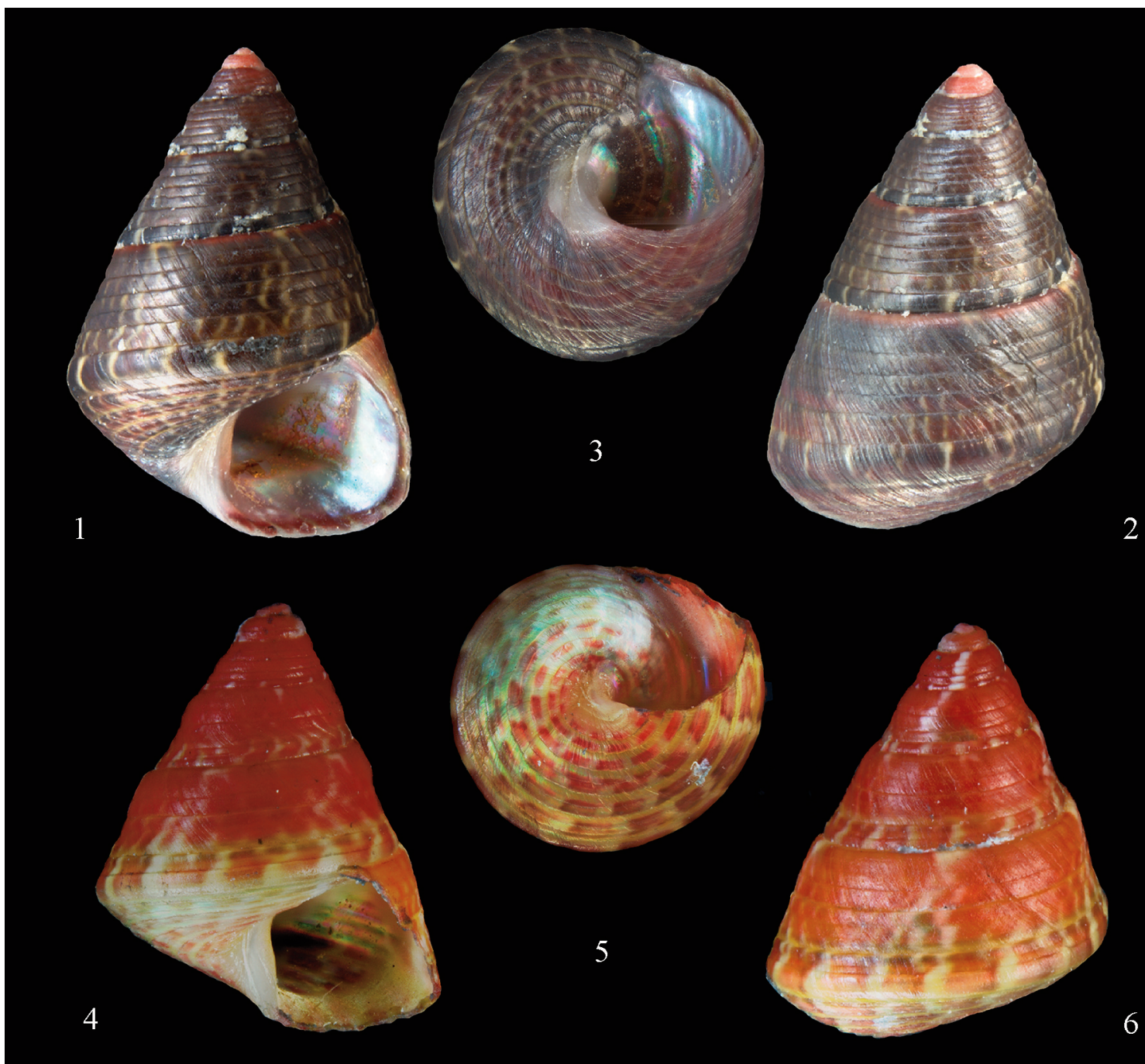

Figures 1-3. Jujubinus browningleeae n. sp., holotype (RBINS: I.G.33787/MT.3687), $5.2 \mathrm{~mm}(\mathrm{H}) \times 3.8 \mathrm{~mm}$ (D), from the type locality (Gorringe Bank, eastern North Atlantic Ocean). Figures 4-6. Jujubinus browningleeae n. sp., paratype (FS), $3.8 \mathrm{~mm}(\mathrm{H}) \times 3.3 \mathrm{~mm}(\mathrm{D})$, from the type locality (Gorringe Bank, eastern North Atlantic Ocean). 


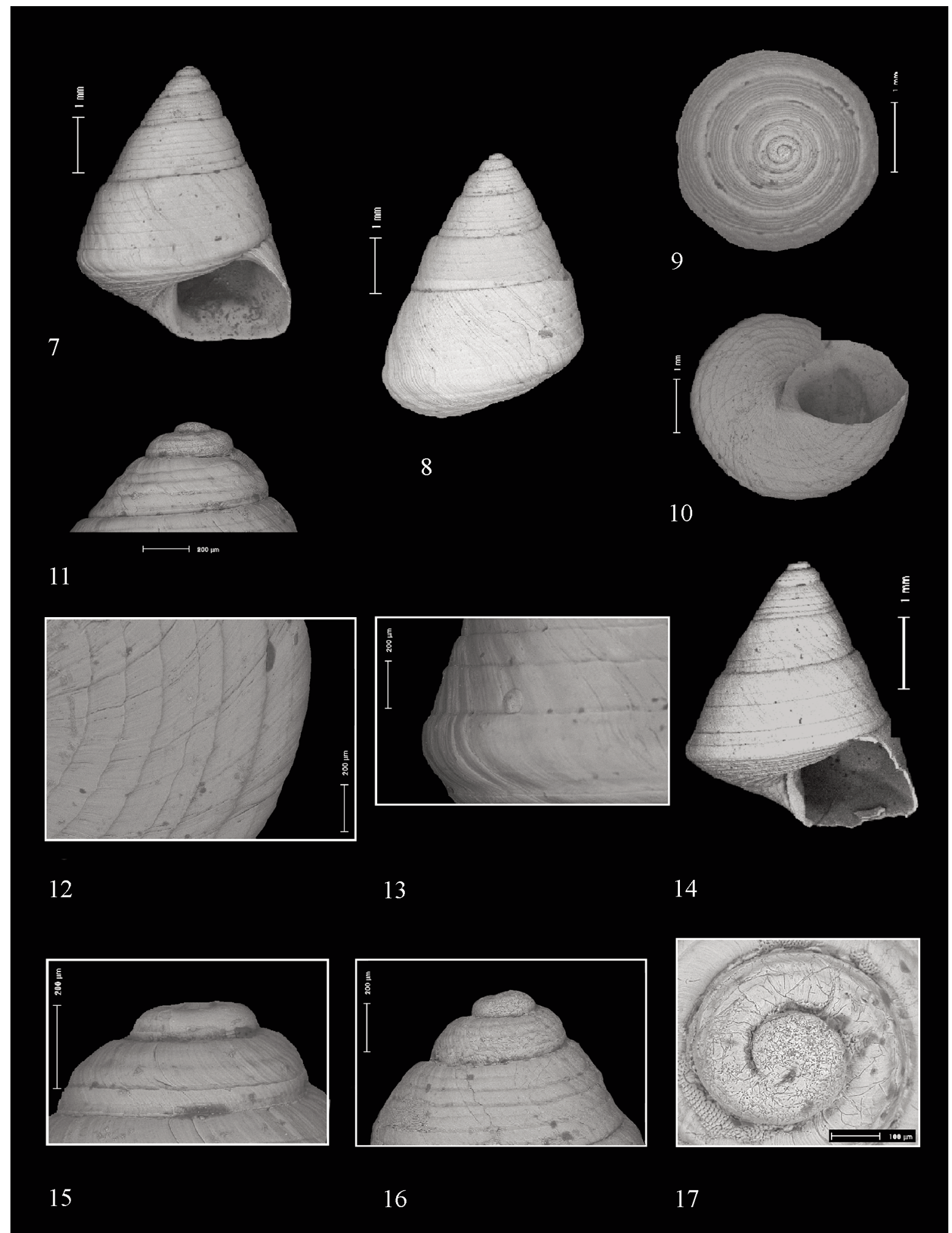

Figures 7-13. Jujubinus browningleeae n. sp., holotype, SEM analyses, details of the shell. (Gorringe Bank, eastern North Atlantic Ocean). Figures 14-17. Jujubinus browningleeae n. sp., paratype (FS), Gorringe Bank, eastern North Atlantic Ocean). 
ous efforts over a three year period in collecting sand/sediment samples in the marine environments of Ascension Island for identification of micro molluses.

REMARKs. The $J$. browningleeae n. sp. (Figs. $1-6,7-17,22)$ differs from all of Mediterranean and Atlantic Jujubinus species by its teleoconch sculpture with flat spiral cords, lacking the typical prosocline lamellae in the spiral furrows between cords (Fig. 23), while it resembles the members of the "smooth" group. In fact, the SEM analysis has confirmed the lack of prosocline lamellae in the shells of the new species, and for this reason it can be ascribed to the "smooth" Jujubinus complex. The members of this complex share other features, e.g., small size, conical and slightly turriculate outline, teleoconch surface covered by faint prosocline growth striae. In spite of these common mor-

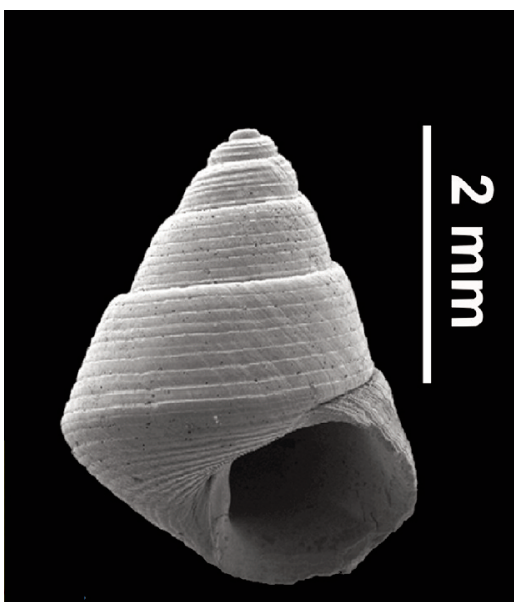

18

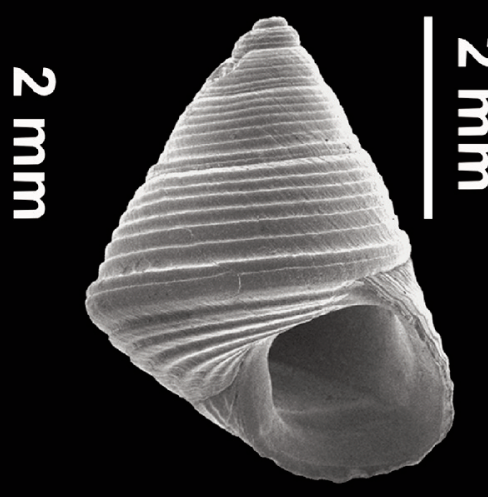

19

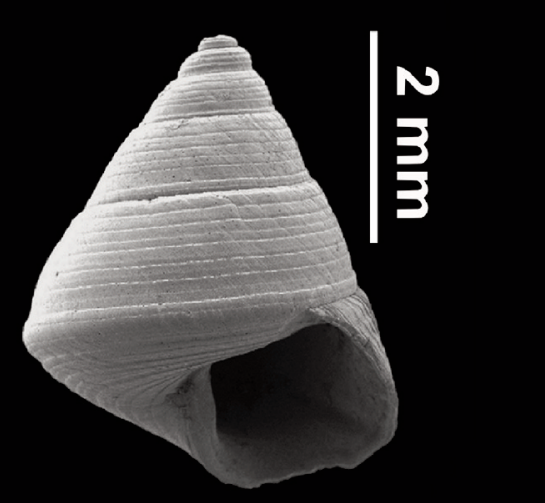

20

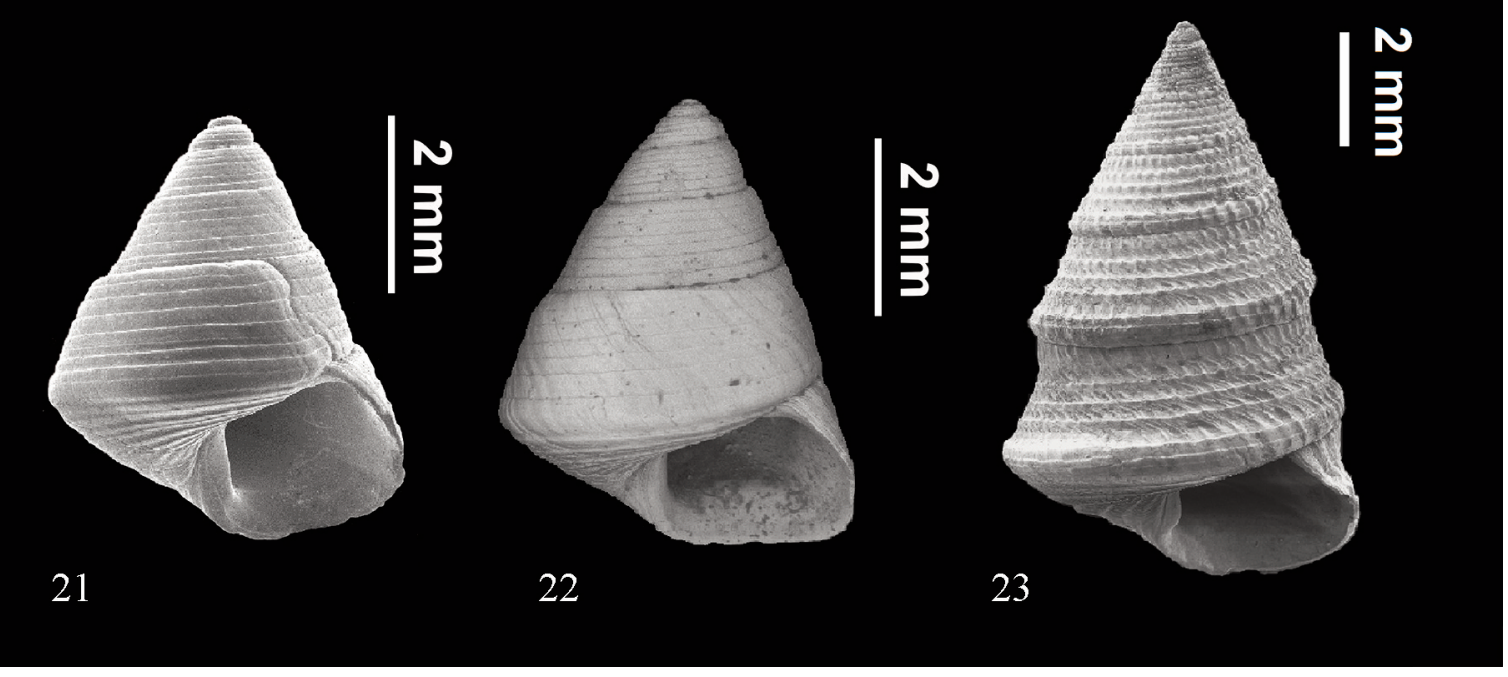

Figures 18-23. Jujubinus curinii species complex. Fig. 18: Jujubinus curinii, Scilla, $42 \mathrm{~m}$ depth, Strait of Messina, Mediterranean Sea (CS-PM). Fig. 19: Jujubinus eleonorae, holotype (MNHN 25883), Skerki Bank (3745’00'”N, 1050'00”'E), infralittoral bottom, $37 \mathrm{~m}$ depth, Sicily Channel, Mediterranean Sea. Fig. 20: Jujubinus trilloi, holotype (MNHN 25882),

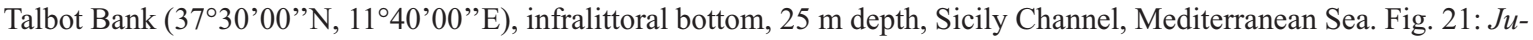
jubinus alboranensis, paratype 6, Alboràn Island ( $\left.35^{\circ} 56^{\prime} 43.99^{\prime}{ }^{\prime} \mathrm{N}, 3^{\circ} 02^{\prime} 03.73^{\prime} \mathrm{W}\right), 30-37 \mathrm{~m}$ depth, amidst Laminaria forest,

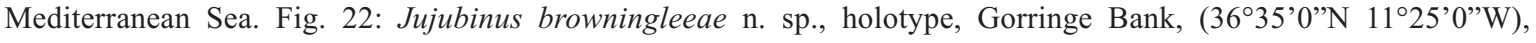
eastern North Atlantic Ocean. Fig. 23: Jujubinus exasperatus $10.2 \mathrm{~mm}(\mathrm{H})$ x $6.6 \mathrm{~mm}$ (D), Giannutri Island (42 $15^{\prime} 7.05^{\prime}$ 'N, $11^{\circ}$ 5'31.51'E), $10 \mathrm{~m}$ depth, on Posidonia beds Mediterranean Sea. 
phological features, the new species differs from: i) J. curinii by its less incised suture, more convex teleoconch whorls and the different colour pattern; ii) J. eleonorae, by its more conical shape, the less ratchet spiral sculpture and the different colour pattern; iii) J. trilloi by its lower H/D ratio (1.2 vs 1.4 , respectively), less convex teleoconch whorls and the different colour pattern; iv) $J$. alboranensis by its smaller size, less turriculate outline and the different colour pattern. The new species is enlarging the number of the components of this "smooth" Jujubinus complex, probably originated from a common ancestor. Interestingly, a fossil specimen of $J$. curinii has been found in the geologic stage of "Milazziano" (Tyrrhenian, Pleistocene) located at Capo Milazzo, North-Eastern Sicily (Smriglio et al., 2017). Each species of this complex seems to be endemic and occurs in small geographical spots (Fig. 24). In fact, the new species is known only from the type locality, the Gorringe Bank, North-Eastern Atlantic Ocean (Fig. 24), a high ranked Ecologically or Biologically Significant Area (EBSA), which recently has been included in the list of Sites of Community Importance of Portugal (Ramos et al., 2015). The habitat of seamounts is often very peculiar due to the hydrological and sedimentary dynamics occurring in these submarine environments (FernándezPalacios et al., 2011; Tittley et al., 2014). These geographical oceanic spots are considered models for marine speciation, due to their distance from the mainland that remained unchanged after their geological formation (Fernández-Palacios et al., 2011; Tittley et al., 2014). Larval dispersion capability represents the only process which ensures to benthic communities colonization and a high level of endemism can be generally observed (Gofas, 2018 and references therein). Currently, J. browningleeae $\mathrm{n}$. sp. is the first case of a "smooth" Jujubinus occurring in the North-Eastern Atlantic Ocean, while all the other members of the complex are occurring in the Mediterranean Sea. According to the general circulation of the surface water pattern within the Mediterranean Sea, the Atlantic waters enter the Mediterranean through the Strait of Gibraltar, and the inflow is first directed westeastward along the African coast, mainly due to the Coriolis force (El-Geziry \& Bryden, 2010).

It has been calculated that two thirds of the total amount of this Atlantic water current turn Southward through the Strait of Sicily, while one third flows anticlockwise around the Tyrrhenian Sea passing along Sicily and the Italian Peninsula before entering the Channel of Corsica (Bethoux, 1980). Interestingly, the collecting sites of the members of the "smooth" Jujubinus complex are overlapping on the surface water current described above and distributed along geographical regions interested by the above mentioned current, suggesting that the complex could be originated from an Atlantic congener ancestor, which entered into the Mediterranean basin and colonized some pe-

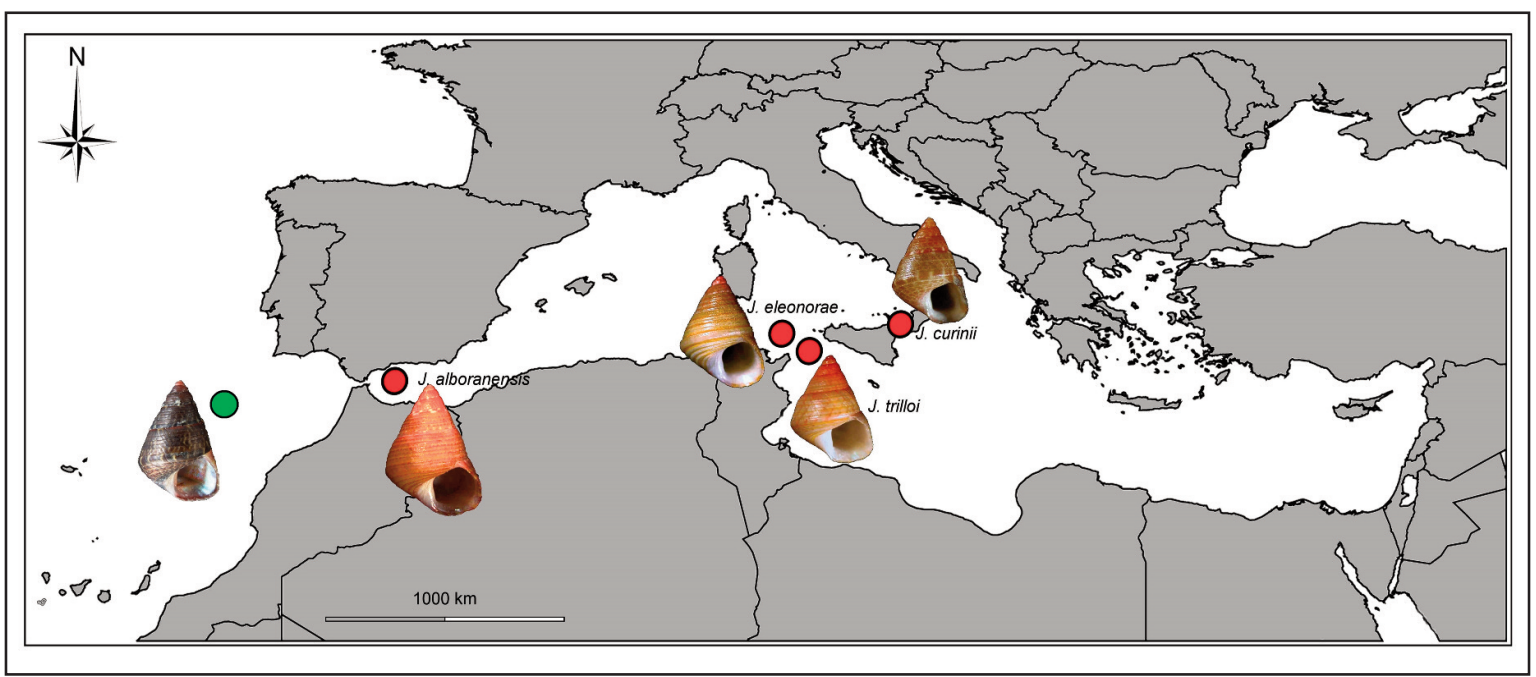

Figure 24. Distribution of Jujubinus browningleeae n. sp. (green point) and other species of the J. curinii complex (red points). 
culiar habitats of the Alboran Sea (J. alboranensis), the Sicily Strait (J. eleonorae and J. trilloi) and the Messina Strait (J.curinii). It is noteworthy to recall that Mediterranean animals of the Jujubinus genus, with few exceptions, are generally associated to algal turfs and/or seagrass beds in the photophilic zone, usually at the interdital zone. In this regard, a specimen of $J$. trilloi has been depicted by Trainito \& Baldacconi (2014: 178), misidentified as $J$. catenatus Ardovini, 2006. This living individual is grazing on microalgae epiphytes upon Phyllariopsis brevipes (C. Agardh) E.C. Henry et G.R. South from the Skerki Bank (E. Trainito, personal communication), suggesting that a possible habitat for the members of the "smooth" Jujubinus complex could be marine bottoms hosting kelps (Laminariales). Shells of $J$. alboranensis have been screened out from bioclastic sediment collected amidst Laminaria forest at 30-37 m depth (Smriglio et al., 2015). The presence of the kelps Saccorizha polyschides (Lightfoot) Batters, Laminaria rodriguezii Bornet and $L$. ochroleuca Bachelot de la Pylaie in the Strait of Messina (Drew, 1974; Zampino \& Di Martino, 2000) where $J$. curinii occurs, as well as the occurrence of Laminariales in both Skerki and Talbot Banks, where J. eleonorae and J. trilloi are present, support the hypothesis of a trophic association between the Mediterranean "smooth" Jujubinus and kelps. According to Tittley et al. (2014), the kelps Laminaria ochroleuca and Saccorhiza polyschides occur in the Gorringe Bank, so a possible link between $J$. browningleeae $n$. sp. and one of these two kelps can be hypothesized as a potential trophic association. A molecular phylogenetic study of this peculiar Jujubinus group is advisable to clarify the current relationships among species of the "smooth" Jujubinus group and in respect to all other congeners.

\section{ACKNOWLEDGEMENTS}

Sincere thanks are due to Andrea Di Giulio and Giulia Scarparo (Dipartimento di Scienze, Università "Roma Tre", Rome, Italy) for the SEM photographs carried out at the LIME and the optical photographs taken by stereomicroscope equipment. We would like to express our gratitude to Massimo Appolloni (Museo Civico di Zoologia di Roma,
Rome, Italy) for the examination of the Jujubinus material kept in the Monterosato collection.

\section{REFERENCES}

Anonymous, 2005. The seamounts of the Gorringe Bank. Oceana, Madrid. http://eu.oceana.org.

Bethoux J.P., 1980. Mean water fluxes across sections in the Mediterranean Sea, evaluated on the basis of water and salt budgets and observed salinities. Oceanologica Acta, 3: 79-88.

Bogi C. \& Campani E., 2006. Jujubinus curinii n. sp. una nuova specie di Trochidae per le coste della Sicilia. Bollettino Malacologico, 41: 99-101.

Crosse C.H., 1885. Journal de Conchylilogie comprenant l'étude des mollusques vivent et fossiles, 5. 3' série, Tome 25, $140 \mathrm{pp}$.

Drew E.A., 1974. An ecological study of Laminaria ochroleuca Pyl. growing below 50 metres in the Straits of Messina. Journal of Experimental Marine Biology and Ecology, 15: 11-24.

El-Geziry T.M. \& Bryden I.G., 2010. The circulation pattern in the Mediterranean Sea: issues for modeller consideration. Journal of Operational Oceanography, 3: 39-46. DOI: 10.1080/1755876X.2010.11020116

Fernández-Palacios J.M., de Nascimento L., Rüdiger O., Delgado J.D., García-del-Rey E., Arévalo J.R. \& Whittaker R.J., 2011. A reconstruction of Paleo-Macaronesia, with particular reference to the long-term biogeography of the Atlantic island laurel forests. Journal of Biogeography, 38: 226-246. DOI: 10. 1111/j.1365-2699.2010.02427.x

Gofas S., 2018. A non-planktotrophic haloceratid (Gatropoda) from the Meteor seamount group, central North Atlantic. Iberus, 36: 1491-1555.

Hall-Spencer J., Clark M., Consalvey M., Rowden A., Stocks K. \& Schlacher T., 2011. A celebration of life on seamounts. Porcupine Marine Natural History Society Newsletters, 30: 54-56.

Mariottini P., Di Giulio A., Apolloni M. \& Smriglio C., 2013. Phenotypic diversity, taxonomic remarks and updated distribution of the Mediterranean Jujubinus baudoni (Monterosato, 1891) (Gastropoda, Trochidae). Biodiversity Journal, 4: 343-354.

Monterosato T. Di Maria, 1884. Conchiglie littorali mediterranee. Il Naturalista siciliano, Palermo, 3: 102-111. In: Giannuzzi Savelli R. (Ed.) 1983, Opera Omnia (1878-1885). Vol. II. Cartografica M. Giordano, Palermo, pp. 373-809.

Ramos M., Bertocci I., Tempera F., Calado G., Albuquerque M. \& Duarte P., 2015. Patterns in megabenthic assemblages on a seamount summit (Ormonde Peak, Gorringe Bank, Northeast Atlantic). Marine Ecology, 37: 1-16. DOI: 10.1111/maec.12353 
Smriglio C., Di Giulio A. \& Mariottini P., 2014. Description of two new Jujubinus species (Gastropoda: Trochidae) from the Sicily Channel. With notes on the Jujubinus curinii species complex. Zootaxa, 3815: 583-590. DOI: 10.11646/zootaxa.3815.4.8

Smriglio C., Mariottini P. \& Appolloni M., 2017. First record of Jujubinus curinii Bogi et Campani, 2006 (Gastropoda Trochidae) in north-eastern Sicily (Italy). Biodiversity Journal, 8: 943-946.

Smriglio C., Mariottini P. \& Oliverio M., 2015. A new species of the Jujubinus curinii species complex: Jujubinus alboranensis spec. nov. (Gastropoda: Trochidae) from the Alborán Sea. Iberus, 33: 151-157.

Staudigel H., Koppers A.A.P., Lavelle J.W., Pitcher T.P.J.
\& Shank T.M., 2010. Defining the word "seamount". Oceanography, 23: 20-21.

Tittley I., da Silva Vaz Álvaro N.M. \& de Melo Azevedo Neto A.I., 2014. Preliminary observations on the benthic marine algae of the Gorringe seabank (northeast Atlantic Ocean). Helgoland Marine Research, 68: 307-312.

Trainito E. \& Baldacconi R., 2014. Atlante di Flora e Fauna del Mediterraneo. Ed. Il Castello, Milano, 432 pp.

Zampino D. \& Di Martino V., 2000. Presentazione cartografica dei popolamenti a laminariales dello stretto di Messina - Cartographical restitution of communities with laminarales of the straits of Messina. Biologia Marina Mediterranea, 7: 599-602. 